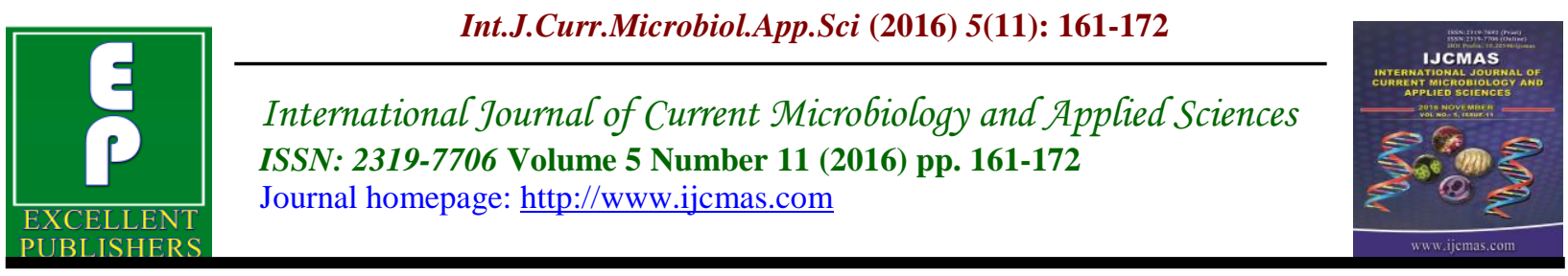

Original Research Article

http://dx.doi.org/10.20546/ijcmas.2016.511.019

\title{
Assessment of Biofilm Production and Antibiotic Pattern in E. faecium and E. faecalis isolated from Some UTI Iraqi Patients
}

\author{
Aya H. Alhalaby* and Ashwak B. J. Al-Hashmiy \\ Genetic Engineering and Biotechnology Institute for Postgraduate Studies, \\ Bagdad University, Iraq \\ *Corresponding author
}

Keywords

E. faecium and

E. faecalis,

Biofilm

Production, Antibiotic Pattern.

Article Info

Accepted:

12 October 2016

Available Online:

10 November 2016
A B S T R A C T

Total of (104) urine samples were collected from patients suffering from urinary tract infection with different age groups from five hospitals in Baghdad (IbnAlbalady, Al Yarmouk, Medical city, Baghdad hospital and Al-Kandy) from the period of the beginning of September 2015 to the end of December 2015.All samples were examined by traditional methods based on cultural characteristics, biochemical test and API 20 strep. The results showed the revealed of 50 isolates to Enterococcus and this confirmed by polymerase chain reaction technique based on amplification of species specific genes. Antimicrobial susceptibility testing of the fifty isolates were screened by disc diffusion method on Mueller-Hinton agar using 10 types of antibiotics which differ in their action includes (Ampicillin, Cefepime, Imipenem, Vancomycin, Rifampicin, Erythromycin, Ofloxacin, Oxacillin Oxytetracycline, and Streptomycin),results show $100 \%$ of isolates resist to six types of antibiotics (Cefepime, vancomycin, rifampicin, erythromycin, oxacillin and oxytetracyclin) and showed different pattern of resistance to the others four antibiotics. On the other hand we use two methods, Congo red agar(CRA) and microtitre plate method (MTP) to detect Enterococcus biofilm production. Results of (CRA) methods show that 22(44\%) detect as strong, 25(50\%) as moderate and $3(6 \%)$ as week biofilm production, while for (MTP) method results show that $20(40 \%)$ detect as strong, 26(52\%) as moderate and $4(8 \%)$ as week biofilm production. This study aimed to describe antibiotic resistance of E. faecalis and $E$. faecium and it role in biofilm formation from bacterial isolates.

\section{Introduction}

Urinary tract infections (UTIs) comprise one of the largest classes of infections occurring in both hospital and community (Peleg and Hooper, 2010; Broeren et al., 2011). UTI are classified as uncomplicated or complicated (Stamm et al., 2001). Uncomplicated UTIs occur in sexually active healthy female patients with structurally and functionally normalurinary tracts.
Complicated UTIs are those that are associated with comorbid conditions that prolong the need for treatment or increase the chances for therapeutic failure. These conditions include abnormalities of the urinary tract that impede urine flow, the existence of a foreign body (e.g., indwelling catheter, stone), or infection with multidrug resistant pathogens (Hooton, 2000; Stapleton, 2003). 
Enterococcus are intrinsically resistant to many antibiotics and are able to acquire drug resistance either by chromosome, transfer of plasmid or transposon acquisition containing genetic sequences that confer resistance in other bacteria (Belgacem et al., 2010; Hammerum et al., 2010).

Biofilms are an important factor in the pathogenesis of Enterococcus infections (Mohamed et al., 2004). Biofilms are not only resistant to antibiotics but a variety of disinfectants (Chenand Wen, 2011).

Biofilm producing bacteria are responsible for many recalcitrant infections and are notoriously difficult to eradicate. They exhibit resistance to antibiotics by various methods like restricted penetration of antibiotic into biofilm and expression of possible resistance genes (Lewis, 2001).

\section{Materials and Methods}

\section{Clinical Isolates}

Total of (104) urine samples were collected from patients suffering from urinary tract infection with different age groups from five hospitals in Baghdad (Ibn- Albalady, Al Yarmouk, Medical city, Baghdad hospital and Al-Kandy) from the period of the beginning of September 2015 to the end of December 2015.

\section{Isolation and identification of Enterococcus by Traditional methods}

\section{Culturing on selective media}

The isolates were identified by characteristic colony morphology of Enterococcus on selective media (bile esculin agar) which gave round shape colony with slightly convex smooth edges, creamy color and convert media into black.

\section{Molecular identification of Enterococcus Bacterial Genomic DNA Extraction}

Genomic DNA was extracted from the bacterial isolates using Presto Mini g DNA bacteria Kits extraction Genomic DNA, Purification depending on instruction of manufacturing company (Geneaid, Thailand).

\section{Detection of Enterococcus by Molecular Method}

Detection of Enterococcus speciesby use species specific primer

Multiplex PCR used for conformation identification of the E.faecalis and E.faecium, reaction was conducted in $20 \mu \mathrm{l}$ of reaction mixture containing $13 \mu \mathrm{l}$ of distilled water, PCR master mix (Bioneer Corporation), $1 \mu 1$ forward from each genes and $1 \mu 1$ reverse primer from each genes, the sequence of primer mention in table (1), finely $3 \mu \mathrm{l}$ of DNA added (table-2).

Amplification was conducted using a DNA thermal cycler programmed with 30 cycles included initial denaturation at $94^{\circ} \mathrm{C}$ for 10 min, denaturation at $94^{\circ} \mathrm{C}$ for $1 \mathrm{~min}$, annealing at $58^{\circ} \mathrm{C}$ for $1 \mathrm{~min}$, extension at $72^{\circ} \mathrm{C}$ for $1 \mathrm{~min}$ and a final extension at $72^{\circ} \mathrm{C}$ for $10 \mathrm{~min}$ as show in table (3), for PCR products were analyzed in agarose gels and visualized under UV after staining with ethidium bromide.

\section{Antibiotics Susceptibility Test (11)}

Few colonies of identical bacteria were picked up from an agar plate (fresh culture $24 \mathrm{~h}$ old) and suspended until a turbidity equivalent to $0.5 \mathrm{McFarland}$. Sterile swab was dipped into inoculums tube, streaked over the surface of the Mueller-Hinton medium then left to dry. A maximum of five 
antibiotic disks were placed on the plate, incubated for 24 hour at $37^{\circ} \mathrm{C}$. The resulting zones of inhibition were measured by a ruler and compared with the zones of inhibition determined by CLSI (2013).

\section{Biofilm production test}

\section{Congo Red Agar method}

A specially prepared medium known as Congo Red Agar (CRA) is used for this test. The Enterococcus strains were inoculated onto CRA and incubated at $37^{\circ} \mathrm{C}$ for $24 \mathrm{~h}$. Readings were taken after $24 \mathrm{~h}$ and again after $48 \mathrm{~h}$. A positive result was indicated by black colonies with black crystalline morphology. Non-biofilm producers mostly produced pink- or red-colored colonies (Freeman et al., 1989).

\section{Microtiter plate methods}

A modified tissue culture plate method was used as described by Mirzaee et al., (2014). Briefly, the wells of microtitre plate were filled with $200 \mu \mathrm{l}$ of brain heart broth (BHB) supplemented with $.5 \%$ glucose. Then, a 20 $\mu$ quantity of previously prepared bacterial suspensions with turbidity equal to 0.5 McFarland standards was added to each well (3 well for each strain). The negative control wells contained $200 \mu \mathrm{l}$ of BHB supplemented with 5\% glucose. Incubation at $37^{\circ} \mathrm{C}$ for $24 \mathrm{~h}$ before removal of the cultures.

Then, the cells were decanted, and each well was washed 3-times with sterile phosphate buffered saline dried in an inverted position and stained with $1 \%$ crystal violet for 20 minutes. The wells were rinsed again with distilled water and crystal violet was solubilized in $200 \mu \mathrm{l}$ of ethanol. The OD was measured at $490 \mathrm{~nm}$ using a micro ELISA auto reader and considered as an index of bacteria adhering to surface and forming biofilms (table-4).

\section{Results and Discussion}

\section{Clinical Samples}

\section{Identification of Enterococcus by Traditional methods}

Fifty isolates identify as Enterococcus on bile esculin agar Fig(1) depend on creamy color of colony which conversion of media to black, it consist of $40 \%$ bile salt help in inhibition growth of Streptococci belong to group D antigen made this media useful in diagnosis of Enterococcus from other nonEnterococcus bacteria that belong to group D antigen (MacFaddin, 2000).

The API 20 strep system was used for accurate identification of the isolates at generic and species level, the test gave positive results for all isolates as show in fig.(2).

\section{Identification of Enterococcus species by molecular methods}

Multiplex PCR technique were used for the diagnosis of all (50) isolates which has grown on the selective media and has already been diagnosed based on their morphology characteristic on culture media and biochemical test, use species-specific primers for the D-alanine-D-alanine ligase gene (ddl E.faecalis and ddl E.faecium) which was specific for diagnosis of E.faecalis and E.faecium, it give same result of biochemical test (API 20 strep) 28bacteria isolates for E.faecalis and 22 bacteria isolates for E.faecium, similar finding was reported by Comerlato et al. (2013),piece that amplify by PCR detect by using gel electrophoresis as show in fig(3).

\section{Antibiotics Susceptibility Test}

Antibiotic sensitivity test was conducted for 50 Enterococcus isolates (twenty eight 
isolates of E.faecalis and twenty two isolates for E.facium) using 10types of antibiotics with different action, the percentage of resistance show in table (5).

The results showed that $(100 \%)$ of E.faecalis and E.faecium were resist to (cefepime, vancomycin, rifampicin, erythromycin, oxacillin and oxytetracycline), while $95.4 \%$ of E.faecium and $89.2 \%$ of E.faecalis were resist to ampicillin and ofloxacin respectively.

On the other hand $77.2 \%$ of E.faecium and $78.5 \%$ of E.faecalis were resist to impenem, $81.1 \%$ of E.faecium and $92.8 \%$ of E.faecalis were resist to streptomycin.

This matching of results correlated with the previous study in Iraq (Al-Shamary, 2011 and AL-Marjani, 2013) and other study in the world (Al-Ruwaili et al., 2012 and Sharifi et al., 2012).

\section{Detection of biofilm production}

All isolates of bacteria grow in Congo red agar for detection biofilm production as show in fig.(4). The results show that $26(92.8 \%)$ of E.faecalis produce biofilm (strong and moderate) while $2(7.1 \%$ ) were weak biofilm production, $21(95 \%)$ isolates of E.faecium were biofilm production (strong and moderate) while one isolate $(4.5 \%)$ was weak biofilm production as show in table (6).

Such a high percentage of biofilm production in our results was agree partially with study obtain by Mohamad and El Shalakan (2016) who find that $(85.7 \%)$ of E.faecalis were slimes producer on CRA plates, also this results agree with study done by Sieńko et al.(2015) who find that the ability to produce biofilm was detected in $90 \%$ of E.faecium.
In MTP methods we use polystyrene plate of 96 wells for detection of biofilm production as show in fig. (5).

Our results show $11(39 \%)$ isolates of E.faecalis detect as strong biofilm production, $14(50 \%)$ isolates as intermediate and $3(10 \%)$ as weak biofilm production, close to these results was reported by Mohamed et al., (2004) who find 39\% of isolates strong, 52\% moderate and $9 \%$ of isolates weak biofilm production.

The percentage of biofilm formation in E.faecium was $9(40 \%)$ as strong, $12(54.5 \%)$ moderate and one isolate $(4.5 \%)$ as weak biofilm production as show in table (7).

These results partially agree with Diani et al., (2014) who find that 9(32.14\%) fecal isolates of E.faecium were strong biofilm production, $3(10.7 \%)$ weak biofilm production. On the other hand these results were disagreeing with study of Banerjee and Anupurba (2015) whom found that E.faecalis 39 (25.16\%) and E.faecium 42 $(27.09 \%)$ produce biofilm.

Microtitre plate method were found to be most sensitive, accurate and reliable screening method for detection of biofilm formation when compared to CRA methods, microtitre plate method was quantitative test method and it was considered the gold standard method for biofilm detection (Mathur et al., 2006). Many studies have statistically evaluated the sensitivity and specificity between the two methods. Most of the studies recommend MTP method for general screening on biofilm formation. Knobloch et al., (2002) also found MTP method to be more suitable for biofilm detection as compared to CRA method. Similarly, Hittinahalli et al., (2012) and Ira et al., (2013) found MTP method to be superior to MTP and CRA methods. 
Table.1 The Sequence of Forward and Reverse Primers used in this study

\begin{tabular}{|l|l|l|l|}
\hline \multicolumn{1}{|c|}{ Genes } & \multicolumn{1}{|c|}{ Sequence (5' to 3') } & Size & \multicolumn{1}{c|}{ Reference } \\
\hline ddl E. faecium & F:TTGAGGCAGACCAGATTGACG & 658 & $\begin{array}{l}\text { Sharifi } \text { et al., } \\
(2012)\end{array}$ \\
& R:TATGACAGCGACTCCGATTCC & & $\begin{array}{l}\text { Sharifi } \text { et al., } \\
(2012)\end{array}$ \\
\hline ddl E. faecalis & F:ATCAAGTACAGTTAGTCTTTATTAG & 941 \\
& R:ACGATTCAAAGCTAACTGAATCAGT & & \multicolumn{2}{|c|}{} \\
\hline
\end{tabular}

Table.2 The Mixture of multiplex PCR working solution for detection of Enterococcus species

\begin{tabular}{|c|c|}
\hline Component & Volume $(\boldsymbol{\mu l})$ \\
\hline \hline Primer F. & 2 \\
\hline Primer R. & 2 \\
\hline DNA & 3 \\
\hline Water & 13 \\
\hline Total Volume & $20 \mu \mathrm{l}$ \\
\hline
\end{tabular}

Table.3 PCR Program for detection of DDL E.faecium and DDL E.faecalis genes amplification by multiplex PCR

\begin{tabular}{|l|l|c|c|}
\hline No. & \multicolumn{1}{|c|}{ Steps } & $\begin{array}{c}\text { Temperature } \\
\left({ }^{\circ} \mathbf{C}\right)\end{array}$ & Time \\
\hline $\mathbf{1 .}$ & Initial Denaturation & 94 & $10 \mathrm{~min}$ \\
\hline $\mathbf{2 .}$ & Denaturation & 94 & $1 \mathrm{~min}$ \\
\hline $\mathbf{3 .}$ & Annealing & 58 & $1 \mathrm{~min}$ \\
\hline $\mathbf{4 .}$ & Extension & 72 & $1 \mathrm{~min}$ \\
\hline $\mathbf{5 .}$ & Final extension & 72 & $10 \mathrm{~min}$ \\
\hline $\mathbf{6 .}$ & Cycles number & \multicolumn{2}{|c|}{} \\
\hline
\end{tabular}

Table.4 Interpretation of biofilm production

\begin{tabular}{|c|c|}
\hline OD value & Biofilm production \\
\hline \hline ODc $<\sim \leq 2 \mathrm{x}$ ODc & weak \\
\hline $2 \mathrm{x}$ ODc $<\sim \leq 4 \mathrm{x}$ ODc & Moderate \\
\hline$>4 \mathrm{x}$ ODc & Strong \\
\hline
\end{tabular}

ODc = Optical density of negative control 
Table.5 Percentage of antibiotic resistant in Enterococcus species

\begin{tabular}{|r|c|c|c|}
\hline \multicolumn{1}{|c|}{ Antibiotic } & E.faecium & E.faecalis & Total resist \% \\
\hline Ampicillin(AM) & $95.4 \%$ & $89.2 \%$ & $92 \%$ \\
\hline Cefepime(FEP) & $100 \%$ & $100 \%$ & $100 \%$ \\
\hline Imipenem(IMP) & $77.2 \%$ & $78.5 \%$ & $78 \%$ \\
\hline Vancomycin(VA) & $100 \%$ & $100 \%$ & $100 \%$ \\
\hline Rifampicin(RA) & $100 \%$ & $100 \%$ & $100 \%$ \\
\hline Erythromycin(E) & $100 \%$ & $100 \%$ & $100 \%$ \\
\hline Ofloxacin(OFX) & $95.4 \%$ & $89.2 \%$ & $100 \%$ \\
\hline Oxacillin(OX) & $100 \%$ & $100 \%$ & $100 \%$ \\
\hline Oxtetracycline(OXY) & $100 \%$ & $100 \%$ & $88 \%$ \\
\hline Streptomycin(S) & $81.8 \%$ & $92.8 \%$ & \\
\hline
\end{tabular}

Table.6 Percentage of E.faecalis and E.faecium biofilm production on CRA medium

\begin{tabular}{|c|c|c|c|c|}
\hline $\begin{array}{c}\text { Enterococcus } \\
\text { species }\end{array}$ & $\begin{array}{c}\text { Number of } \\
\text { isolates }\end{array}$ & Strong & Moderate & weak \\
\hline E.faecalis & 28 & $12(42.8 \%)$ & $14(50 \%)$ & $2(7.1 \%)$ \\
\hline E.faecium & 22 & $10(45.4 \%)$ & $11(50 \%)$ & $1(4.5 \%)$ \\
\hline Total & 50 & $22(44 \%)$ & $25(50 \%)$ & $3(6 \%)$ \\
\hline
\end{tabular}

Table.7 percentage of E.faecalis and E.faecium biofilm production by (MTP) method

\begin{tabular}{|c|c|c|c|c|}
\hline $\begin{array}{c}\text { Enterococcus } \\
\text { species }\end{array}$ & $\begin{array}{c}\text { Number of } \\
\text { isolates }\end{array}$ & strong & Moderate & Weak \\
\hline E.faecalis & 28 & $11(39 \%)$ & $14(50 \%)$ & $3(10 \%)$ \\
\hline E.facium & 22 & $9(40.9 \%)$ & $12(54.5 \%)$ & $1(4.5 \%)$ \\
\hline Total & 50 & $20(40 \%)$ & $26(52 \%)$ & $4(8 \%)$ \\
\hline
\end{tabular}


Fig.1 Appearance of Enterococcus isolates on Bile Esculin Agar.

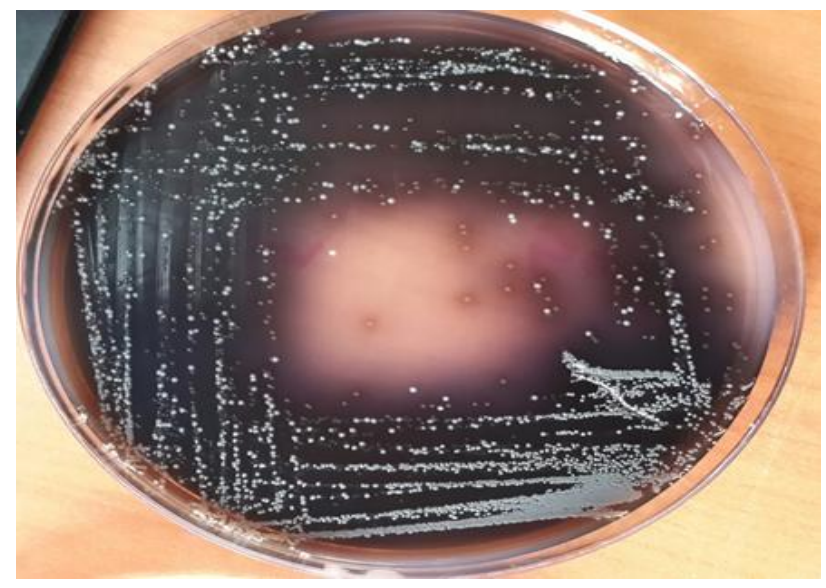

Fig.2 Biochemical identification of Enterococcus using API 20 strep

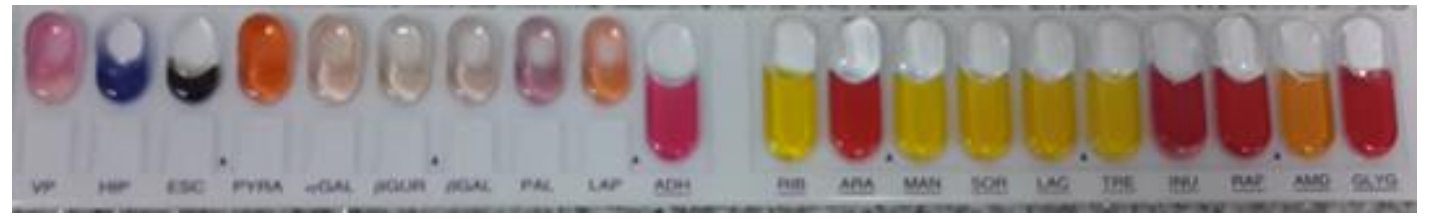

Fig.3 Agarose gel electrophoresis of multiplex PCR for identification Enterococcus species, M: marker (100pb ladder), lanes (1, 2, 3, 5, 7) positive amplification of ddl E.faecium gene (658) $\mathrm{Pb}$, lanes $(4,6,8,9)$ positive amplification of ddl E.faecalis gene (941) $\mathrm{Pb}$.

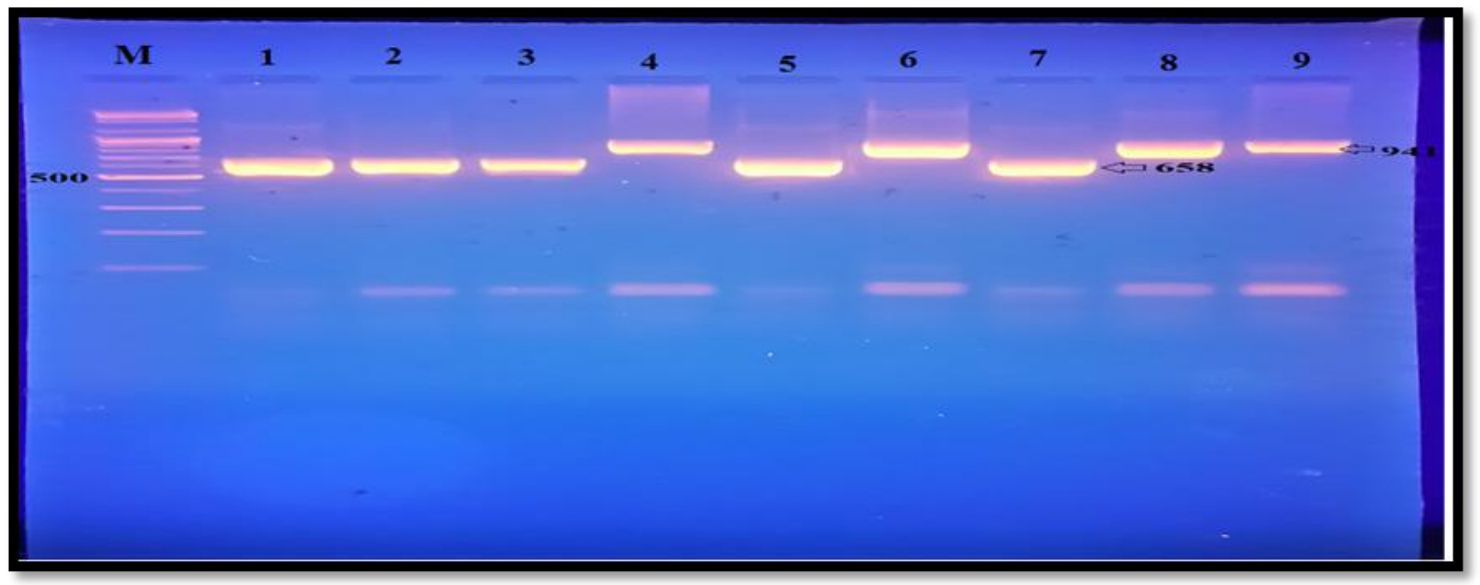


Fig.4 Detection of Enterococcus biofilm production on Congo red agar method

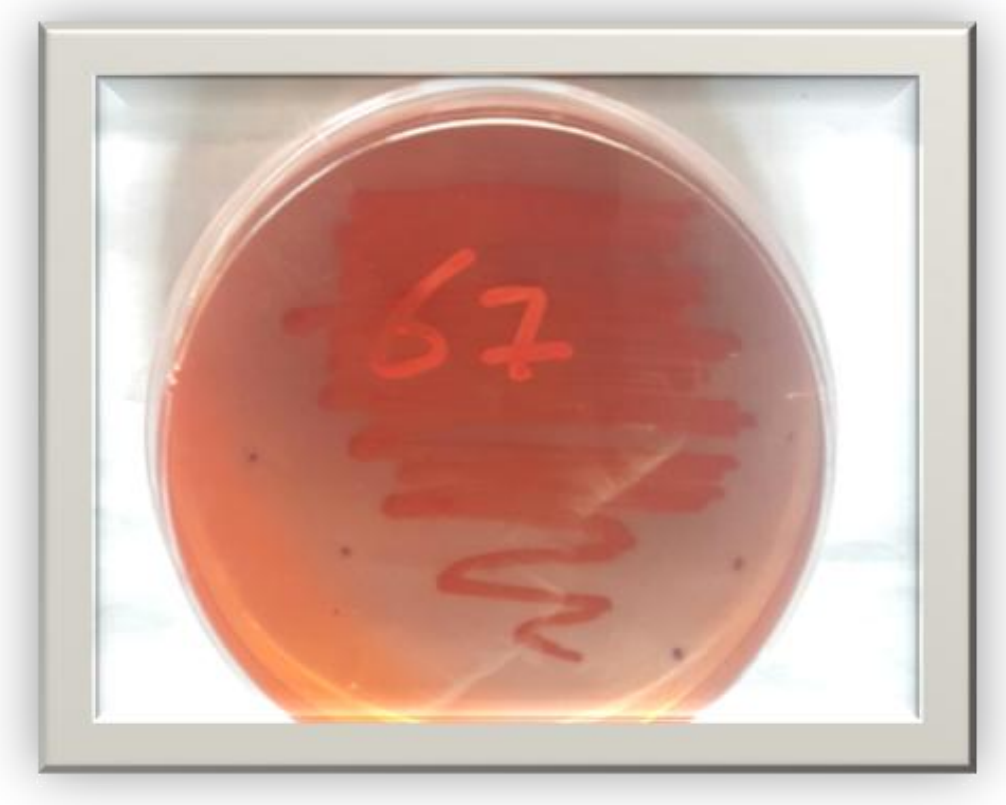

Fig.5 polystyrene plate for detection biofilm in Enterococcus

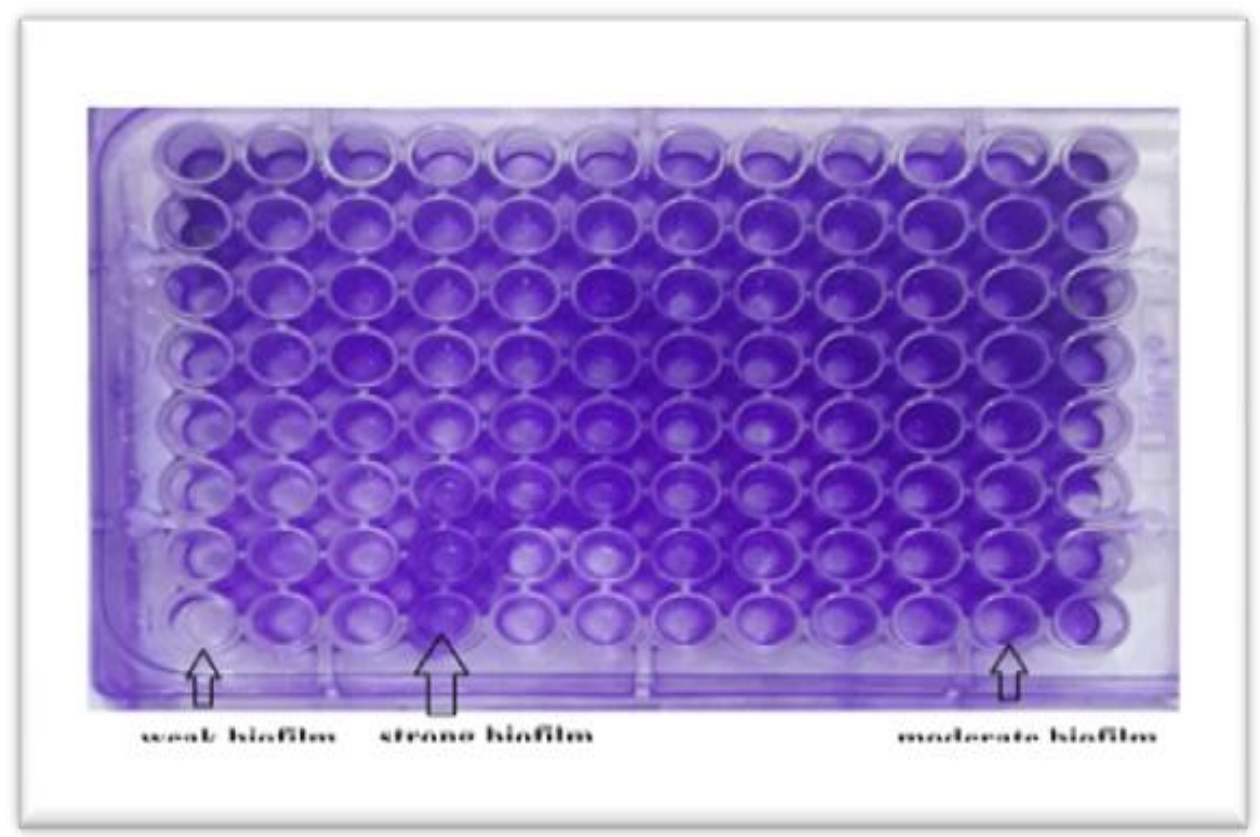


Fig.6 Relation between Enterococcus antibiotic resist and biofilm production

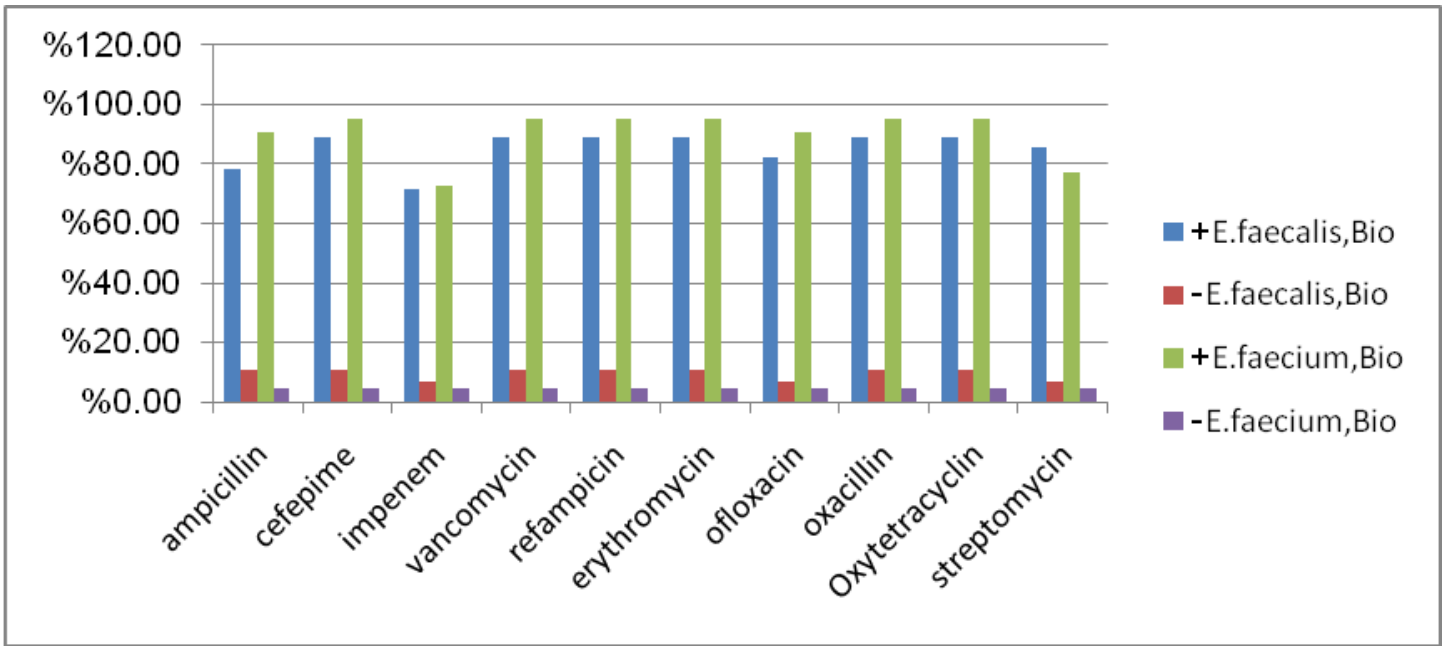

Our results show high antibiotic resist isolates among biofilm positive isolates compere to biofilm negative isolates as show in fig.(6).

Importance of biofilm formation has been described in the control of microbial infection in several areas because the biofilm can increase resistance to various physical and chemical agents, especially antibiotics (Murray and Weinstock, 1999).

Biofilm exhibits more resistance to broad spectrum antibiotics (Mathur et al., 2006), this supports that biofilm adds to the virulence profile of microorganism (Suman et al., 2007).

\section{References}

Akhter, J., Anwar, S., and Ahmed, S. 2012. Enterococcal Virulence Determinants in Urinary Tract Infection Patients. Bangladesh J. Med. Microbiol., 6(1): 14-17.

AL-Marjani, M.F. 2013. vanA in vancomycin-resistant Enterococcus faecalis isolated in Baghdad. African J. Microbiol. Res., (2): 115-119.

Al-Ruwaili, M. A., Khalil, O. M., and Selim, S. A. 2012. Phenotypic and Genotypic differences in the expression of virulence factors in antimicrobial resistance of Enterococcus faecalis clinical strains. Biosci. Res, 9(1): 5058.

Al-Saadi, F. 2007. Study The Resistance of Enterococcus Faecalis that caused Urinary Tract Infection to some Antibiotics \& it's Production for $\beta$ Lactamase Enzymes. MSC. Thesis, Department of Microbiology, AlMustansiriya University, Iraq.

Al-Shamary, M.K. 201.1 Molecular Study of the Vancomycin-Resistant Enterococcus spp M.Sc., Thesis, College of Science AL- Mustansiriyah University.

Banerjee, T., and Anupurba, S. 2015. Prevalence of virulence factors and drug resistance in clinical isolates of Enterococci: A study from North India. J. Pathogens.

Bauer, A. W., Kirby, W. M. M., Sherris, J. C., and Turck, M. 1966. Antibiotic susceptibility testing by a standardized single disk method. American J. Clin. Pathol., 45(4): 493.

Belgacem, Z. B., Abriouel, H., Omar, N. B., Lucas, R., Martínez-Canamero, M., Gálvez, A., and Manai, M. 2010. 
Antimicrobial activity, safety aspects, and some technological properties of bacteriocinogenic Enterococcus faecium from artisanal Tunisian fermented meat. Food Control, 21(4): 462-470.

Broeren, M.A., Bahçeci, S., Vader, H. L., and Arents, N. L. 2011. Screening for urinary tract infection with the Sysmex UF-1000i urine flow cytometer. $J$. Clin. Microbiol., 49(3): 1025-1029.

Castillo-Rojas, G., Mazari-Hiríart, M., de León, S. P., Amieva-Fernández, R. I., Agis-Juárez, R. A., Huebner, J., and López-Vidal, Y. 2013. Comparison of Enterococcus faecium and Enterococcus faecalis strains isolated from water and clinical samples: Antimicrobial susceptibility and genetic relationships. PloS one, 8(4), e59491.

Chen, L., and Wen, Y. M. 2011. The role of bacterial biofilm in persistent infections and control strategies. Int. J. Oral Sci., 3(2): 66.

Comerlato, C. B., Resende, M. C. C. D., Caierão, J., and d'Azevedo, P. A. 2013. Presence of virulence factors in Enterococcus faecalis and Enterococcus faecium susceptible and resistant to vancomycin. Memórias do Instituto Oswaldo Cruz, 108(5): 590595.

Das, R. N., Chandrashekhar, T. S., Joshi, H. S., Gurung, M., Shrestha, N., and Shivananda, P. G. 2006. Frequency and susceptibility profile of pathogens causing urinary tract infections at a tertiary care hospital in western Nepal. Singapore Med. J., 47(4): 281.

Diani, M., Esiyok, O. G., Ariafar, M. N., Yuksel, F. N., Altuntas, E. G., and Akcelik, N. 2014. The interactions between esp, fsr, gelE genes and biofilm formation and pfge analysis of clinical Enterococcus faecium strains.
African J. Microbiol. Res., 8(2): 129137.

Freeman, D. J., Falkiner, F. R., and Keane, C. T. 1989. New method for detecting slime production by coagulase negative staphylococci.J. Clin. Pathol., 42(8): 872-874.

Gulhan, T., Boynukara, B., Ciftci, A., Sogut, M. U., and Findik, A. 2015. Characterization of Enterococcus faecalis isolates originating from different sources for their virulence factors and genes, antibiotic resistance patterns, genotypes and biofilm production. Iranian J. Veterinary Res., 16(3), 261.

Gupta, K., Hooton, T. M., Naber, K. G., Wullt, B., Colgan, R., Miller, L. G., and Soper, D. E. 2011. International clinical practice guidelines for the treatment of acute uncomplicated cystitis and pyelonephritis in women: a 2010 update by the Infectious Diseases Society of America and the European Society for Microbiology and Infectious Diseases. Clin. Infect. Dis., 52(5): e103-e120.

Hammerum, A. M., Lester, C. H., and Heuer, O. E. 2010. Antimicrobialresistant Enterococci in animals and meat: a human health hazard? Foodborne Pathogens and Dis., 7(10): 1137-1146.

Hittinahalli, V., Karjigi, S. K., and Reddy, K. M. 2012. Escherichia coli, Biofilm, Drug Resistance, Congo Red Agar, Tissue Culture Plate. Correlation between Biofilm formation of Uropathogenic Escherichai Coli and its Antibiotic resistance pattern., 68.

Hooton, T.M. 2000. Pathogenesis of urinary tract infections: an update. $J$. Antimicrobial Chemother., 46(suppl 1), 1-7.

Ira, P., Sujatha, S., and Chandra, P. S. 2013. Virulence factors in clinical and 
commensal isolates of Enterococcus species. Indian J. Pathol. Microbiol., 56(1), 24.

Iweriebor, B. C., Obi, L. C., and Okoh, A. I. 2015. Virulence and antimicrobial resistance factors of Enterococcus spp. isolated from fecal samples from piggery farms in Eastern Cape, South Africa. BMC microbial., 15(1), 1.

Johnston, L.M., and Jaykus, L. A. 2004. Antimicrobial resistance of Enterococcus species isolated from produce. Appl. Environ. Microbiol., 70(5): 3133-3137.

Knobloch, J.K.M., Horstkotte, M. A., Rohde, H., and Mack, D. 2002. Evaluation of different detection methods of biofilm formation in Staphylococcus aureus. Med. Microbiol. Immunol., 191(2): 101106.

Kouidhi, B., Zmantar, T., Mahdouani, K., Hentati, H., and Bakhrouf, A. 2011. Antibiotic resistance and adhesion properties of oral Enterococci associated to dental caries. $B M C$ MIcrobiol., 11(1), 1.

Lewis, K. 2001. Riddle of biofilm resistance. Antimicrobial agents and chemotherapy, 45(4): 999-1007.

MacFaddin, J.F. 2000. Biochemical tests for identification of medical bacteria, 3rd ed. Lippincott Williams and Wilkins, Baltimore.

Mathur, T., Singhal, S., Khan, S., Upadhyay, D. J., Fatma, T., and Rattan, A. 2006. Detection of biofilm formation among the clinical isolates of staphylococci: an evaluation of three different screening methods. Indian J. Med. Microbiol., 24(1), 25.

Mirzaee, M., Najar Peerayeh, S., and Ghasemian, A. M. 2014. Detection of icaABCD genes and biofilm formation in clinical isolates of methicillin resistant

Staphylococcus aureus. Iranian J. Pathol., 9(4): 257262.

Mohamad, E.A., and El Shalakan, A.H. 2016. Detection of Biofilm Formation in Uropathogenic Bacteria. The Egyptian J. Med. Microbiol., (EJMM), 24(1).

Mohamed, J. A., Huang, W., Nallapareddy, S. R., Teng, F., and Murray, B. E. 2004. Influence of origin of isolates, especially endocarditis isolates, and various genes on biofilm formation by Enterococcus faecalis. Infection and immunity, 72(6):3658-3663.

Murray, B. E., and Weinstock, G. M. 1999. Enterococci: new aspects of an old organism. Proceedings of the Association of American Physicians, 111(4), 328-334.

Peleg, A.Y., and Hooper, D.C. 2010. Hospital-acquired infections due to gram-negative bacteria. New England J. Med., 362(19): 1804-1813.

Salah, R., Dar-Odeh, N., Hammad, O. A., and Shehabi, A. A. 2008. Prevalence of putative virulence factors and antimicrobial susceptibility of Enterococcus faecalis isolates from patients with dental Diseases. BMC Oral Health, 8(1), 1.

Sharifi, Y., Hasani, A., Ghotaslou, R., Naghili, B., Aghazadeh, M., Milani, M., and Bazmany, A. 2013. Virulence and antimicrobial resistance in Enterococci isolated from urinary tract infections. Adv Pharm Bull, 3(1): 197201.

Sharifi, Y., Hasani, A., Ghotaslou, R., Varshochi, M., Hasani, A., Aghazadeh, M., and Milani, M. 2012. Survey of virulence determinants among vancomycin resistant Enterococcus faecalis and Enterococcus faecium isolated from clinical specimens of hospitalized patients of North west of Iran. The 
Open Microbiol. J., 6(1).

Sieńko, A., Wieczorek, P., Majewski, P., Ojdana, D., Wieczorek, A., Olszańska, D., and Tryniszewska, E. 2015. Comparison of antibiotic resistance and virulence between biofilmproducing and non-producing clinical isolates of Enterococcusfaecium. Acta Biochimica Polonica, 62(4): 859-866.

Stamm, W.E., \& Norrby, S.R. 2001. Urinary tract infections: disease panorama and challenges. $J$.

Infectious Dis., 183(Supplement 1), S1-S4.
Stapleton, A.E. 2003. Urinary tract infections in healthy women. Curr. Treat Opt. Infect. Dis., 5: 43-51.

Suman, E., Jose, J., Varghese, S., and Kotian, M. S. 2007. Study of biofilm production in Escherichia coli causing urinary tract infection. Indian $\mathrm{J}$. Med. Microbiol., 25(3), 305.

Trivedi, K., Cupakova, S., and Karpiskova, R. 2011. Virulence factors and antibiotic resistance in enterococci isolated from food-stuffs. Veterinarni Medicina, 56(7): 352-357.

\section{How to cite this article:}

Aya H. Alhalaby and Ashwak B. J. Al-Hashmiy. 2016. Assessment of Biofilm Production and Antibiotic Pattern in E. faecium and E. faecalis isolated from Some UTI Iraqi Patients. Int.J.Curr.Microbiol.App.Sci. 5(11): 161-172. doi: http://dx.doi.org/10.20546/ijcmas.2016.511.019 